\title{
Summary of the NACI Seasonal Influenza Vaccine Statement for 2020-2021
}

\author{
Kelsey Young ${ }^{1}$, lan Gemmill ${ }^{2,3}$, Robyn Harrison ${ }^{4,5}$ on behalf of the National Advisory Committee on \\ Immunization (NACl)*
}

\begin{abstract}
Background: Evidence on influenza vaccination is continually evolving. The National Advisory Committee on Immunization (NACl) provides annual recommendations to the Public Health Agency of Canada regarding the use of seasonal influenza vaccines.
\end{abstract}

Objective: To summarize NACl's recommendations regarding the use of seasonal influenza vaccines for the 2020-2021 influenza season and to highlight new and updated recommendations.

Methods: 1) To update wording on influenza vaccination of health care workers, $\mathrm{NACl}$ reassessed the evidence in the context of ethics and acceptability frameworks, in accordance with NACl's recently expanded mandate. 2) To provide recommendations on the use of live attenuated influenza vaccine (LAIV) in HIV-infected individuals, the Influenza Working Group developed a predefined search strategy to identify all eligible studies, then assessed the quality and summarized and analyzed the findings according to the $\mathrm{NACl}$ evidence-based process. $\mathrm{NACl}$ provided new recommendations based on assessment of the evidence.

Results: 1) $\mathrm{NACl}$ continues to recommend that health care workers and other care providers in facilities and community settings should be vaccinated annually against influenza and that this group be included among those particularly recommended to receive the influenza vaccine. 2) $\mathrm{NACl}$ concluded that LAIV is immunogenic in children with stable HIV infection; therefore, $\mathrm{NACl}$ newly recommends that LAIV may be considered as an option for children 2-17 years of age with stable HIV infection on highly active antiretroviral therapy and with adequate immune function.

Conclusion: $\mathrm{NACl}$ continues to recommend that an age-appropriate influenza vaccine should be offered annually to anyone six months of age and older who does not have contraindications to the vaccine, with a focus on the groups for whom influenza vaccination is particularly recommended.
This work is licensed under a Creative Commons Attribution 4.0 International License.

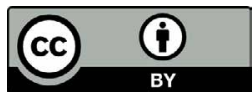

Affiliations

${ }^{1}$ Centre for Immunization and Respiratory Infectious Diseases, Public Health Agency of Canada, Ottawa, ON

${ }^{2} \mathrm{NACl}$ Influenza Working Group Chair

${ }^{3}$ Queen's University, Kingston, ON

${ }^{4} \mathrm{NACl}$ Influenza Working Group Vice Chair

${ }^{5}$ University of Alberta; Alberta Health Services, Edmonton, $A B$

\section{${ }^{\star}$ Correspondence:}

phac.naci-ccni.aspc@canada.ca

Suggested citation: Young K, Gemmill I, Harrison R, on behalf of the National Advisory Committee on Immunization (NACl). Summary of the NACI Seasonal Influenza Vaccine Statement for 2020-2021. Can Commun Dis Rep 2020;46(5):132-7. https://doi.org/10.14745/ccdr.v46i05a06

Keywords: National Advisory Committee on Immunization, $\mathrm{NACl}$, influenza, influenza vaccine, guidance

\section{Introduction}

Seasonal influenza epidemics lead to significant morbidity and mortality in the Canadian population (1) and cause significant strain on the health care system during the influenza season each year. Although the epidemiology of influenza varies from year to year, it is estimated that influenza infections cause an average of 12,200 hospitalizations (2) and 3,500 deaths (3) per year.

Given the cyclical nature of seasonal influenza, the frequent changes to the circulating viral strains, and the number of influenza vaccines authorized for use in Canada, the National Advisory Committee on Immunization (NACl) provides annual recommendations regarding seasonal influenza vaccination to the Public Health Agency of Canada (PHAC). For the 2020-2021 influenza season, NACl has updated the wording used for their recommendation on the vaccination of health care workers $(\mathrm{HCW})$ and has provided a new recommendation on the use of live attenuated influenza vaccine (LAIV) in HIV-infected individuals. Complete details on influenza vaccine can be found 
in the NACI Statement on Seasonal Influenza Vaccine for 2020-2021 (4) and related publications. The objective of this article is to provide a concise summary of the information contained in this annual seasonal influenza statement and to highlight important updates.

\section{Influenza vaccine abbreviations}

The abbreviations used by $\mathrm{NACl}$ have been recently updated to better describe the defining features of the various types of influenza vaccines. The current abbreviations are listed in Table 1.

Table 1: NACl abbreviations for influenza vaccines

\begin{tabular}{|c|c|c|c|}
\hline $\begin{array}{l}\text { Influenza } \\
\text { vaccine } \\
\text { category }\end{array}$ & Formulation & Tyрe & $\begin{array}{l}\text { Current NACl } \\
\text { abbreviation }^{\mathrm{a}}\end{array}$ \\
\hline \multirow{4}{*}{$\begin{array}{l}\text { Inactivated } \\
\text { influenza } \\
\text { vaccine (IIV) }\end{array}$} & \multirow{3}{*}{ Trivalent (IIV3) } & $\begin{array}{l}\text { Standard doseb, } \\
\text { unadjuvanted, } \\
\text { IM administered }\end{array}$ & IIV3-SD \\
\hline & & $\begin{array}{l}\text { Adjuvanted }^{c}, \\
\text { IM administered }\end{array}$ & IIV3-Adj \\
\hline & & $\begin{array}{l}\text { High dosed, } \\
\text { unadjuvanted, } \\
\text { IM administered }\end{array}$ & IIV3-HD \\
\hline & $\begin{array}{l}\text { Quadrivalent } \\
\text { (IIV4) }\end{array}$ & $\begin{array}{l}\text { Standard doseb, } \\
\text { unadjuvanted, } \\
\text { IM administered }\end{array}$ & IIV4-SD \\
\hline $\begin{array}{l}\text { Live } \\
\text { attenuated } \\
\text { influenza } \\
\text { vaccine } \\
\text { (LAIV) }\end{array}$ & $\begin{array}{l}\text { Quadrivalent } \\
\text { (LAIV4) }\end{array}$ & $\begin{array}{l}\text { Unadjuvanted, } \\
\text { Nasal spray }\end{array}$ & LAIV4 \\
\hline \multicolumn{4}{|c|}{ 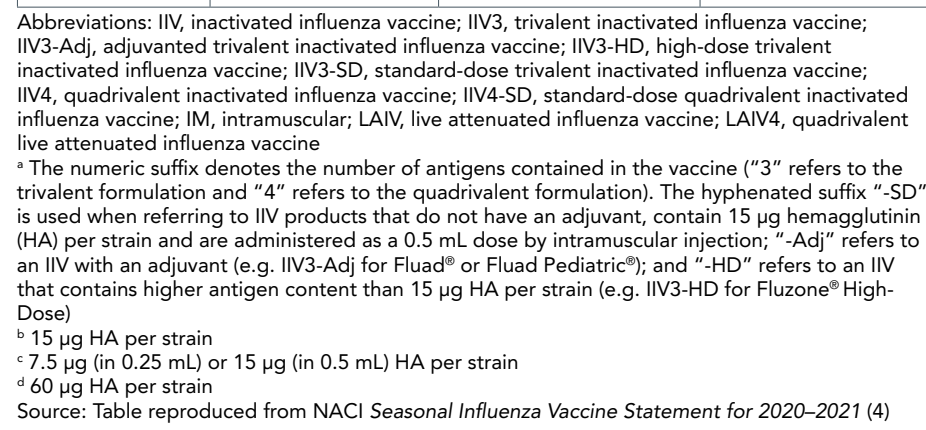 } \\
\hline
\end{tabular}

\section{Methods}

To prepare the Statement on Seasonal Influenza Vaccine for 2020-2021, the Influenza Working Group identified the need for evidence reviews for two topics in particular and, following a review and analysis of the information, proposed new or updated recommendations according to the $\mathrm{NACl}$ evidence-based process (5). NACl critically appraised the available evidence and approved the specific recommendations brought forward.

\section{Vaccination of health care workers and other care providers}

$\mathrm{NACl}$ identified a need to reassess the wording used for the recommendation on the vaccination of $\mathrm{HCWs}$ and other care providers with the influenza vaccine. To inform this updated wording, the evidence from four cluster randomized controlled trials (6-9) that assessed the impact of HCW influenza vaccination in geriatric long-term care settings was reassessed and considered in the context of ethics and acceptability. Ethics and acceptability were systematically considered, based on NACl's approved methods for the evaluation of ethics, equity, feasibility and acceptability as part of NACl's recently expanded mandate.

\section{Use of live attenuated influenza vaccine in HIV-infected individuals}

The NACl Influenza Working Group oversaw the completion of a systematic review to inform the development of guidance on the use of LAIV in HIV-infected individuals. Six electronic databases (MEDLINE, EMBASE, Scopus, ProQuest Public Health Database, ClinicalTrials.gov and PROSPERO) were searched from inception to April 13, 2018 to identify relevant literature on the efficacy, effectiveness, immunogenicity and safety of LAIV in HIV-infected adults and children aged six months and older. The Canadian Adverse Events Following Immunization Surveillance System (CAEFISS) was also searched to identify any reports received on adverse events following vaccination with LAIV in HIV-infected individuals. Two reviewers independently screened the titles and abstracts of records retrieved from the search and eligible full-text articles for inclusion. One reviewer extracted data from eligible studies and appraised the methodological quality of these studies using the criteria outlined by Harris et al. (10). A second reviewer validated the data extraction and quality assessment. A narrative synthesis of the extracted data was performed.

\section{Results}

\section{Vaccination of health care workers and other care providers}

Based on their reassessment of the evidence in the context of ethics and acceptability, $\mathrm{NACl}$ continues to recommend that, in the absence of contraindications, HCWs and other care providers in facilities and community settings should be vaccinated annually against influenza. HCWs and other care providers have the potential to transmit influenza to individuals at high risk and, due to their occupation and close contact with people at high-risk of influenza-related complications, are themselves at increased risk of infection (11). Given the potential to transmit influenza and the increased risk of infection, and knowing that vaccination is the most effective way to prevent influenza, $\mathrm{NACl}$ recommends the inclusion of this group among those particularly recommended to receive the influenza vaccine. $\mathrm{NACl}$ considers 
the receipt of influenza vaccination to be an essential component of the standard of care for all HCWs and other care providers for their own protection and that of their patients. This group should consider annual influenza vaccination as part of their responsibilities to provide the highest standard of care.

Further information on NACl's recommendation for the inclusion of HCWs as a group for whom influenza vaccination is particularly recommended can be found in Section III.2 of the NACI Seasonal Influenza Vaccine Statement for 2020-2021 (4).

\section{Use of live attenuated influenza vaccine in HIV-infected individuals}

The systematic review identified eight articles that reported the findings from five studies investigating the immunogenicity, the safety, or both, of the administration of LAIV in HIV-infected individuals. No studies investigating the efficacy or effectiveness of LAIV in this population were identified. Based on the identified evidence, NACl concluded that LAIV is immunogenic in children with stable HIV infection on highly active antiretroviral therapy (HAART) and with adequate immune function. $\mathrm{NACl}$ also concluded that, while there is insufficient direct evidence to detect uncommon or rare adverse events related to the use of LAIV in HIV infected children, LAIV appears to have a similar safety profile to inactivated influenza vaccine (IIV). In addition, some children and their substitute decision-makers may prefer that they receive influenza vaccine through an intranasal spray as opposed to an intramuscular (IM) injection, although preferences will vary. Regarding the use of LAIV in HIV-infected adults, $\mathrm{NACl}$ concluded that the quantity of evidence available on the immunogenicity and safety of LAIV in adults with HIV is insufficient to justify a recommendation for the use of LAIV in this age group. Based on their assessment of the evidence, $\mathrm{NACl}$ has made the following recommendation:

$\mathrm{NACl}$ recommends that LAIV may be considered as an option for children 2-17 years of age with stable HIV infection on HAART and with adequate immune function* (Discretionary $\mathrm{NACl}$ recommendation).

*LAIV should only be considered in children with HIV who meet the following criteria:

- receiving HAART for $\geq 4$ months

- $\quad$ CD4 count $\geq 500 / \mu \mathrm{L}$ if $2-5$ years of age, or $\geq 200 / \mu \mathrm{L}$ if 6-17 years of age (measured within 100 days before administration of LAIV)

- $\quad$ HIV plasma RNA $<10,000$ copies/mL (measured within 100 days before administration of LAIV)

While IM influenza vaccination is still considered the standard for children living with HIV by $\mathrm{NACl}$ and the Canadian Pediatric and Perinatal HIV/AIDS Research Group, LAIV would be reasonable for children meeting the criteria outlined above, if IM vaccination is not accepted by the patient or substitute decision-maker.
The detailed findings of this review and additional information supporting this recommendation can be found in the $\mathrm{NACl}$ Statement on the Recommendation on the Use of Live-Attenuated Influenza Vaccine (LAIV) in HIV-Infected Individuals (12).

\section{Summary of $\mathrm{NACl}$ recommendations for the use of influenza vaccines for the 2020-2021 influenza season}

$\mathrm{NACl}$ continues to recommend influenza vaccination to anyone six months of age and older who does not have contraindications to the vaccine. Vaccination should be offered as a priority to people at high risk of influenza-related complications or hospitalization, people capable of transmitting influenza to those at high risk of complications, and others as indicated in the List 1 below.

\section{List 1: Groups for whom influenza vaccination is particularly recommended}

People at high risk of influenza-related complications or hospitalization:

- All pregnant women

- Adults and children with the following chronic health conditionsa: - $\quad$ Cardiac or pulmonary disorders (includes bronchopulmonary dysplasia, cystic fibrosis and asthma)

- Diabetes mellitus and other metabolic diseases

- Cancer, immune compromising conditions (due to underlying disease, therapy or both, such as solid organ transplant or hematopoietic stem cell transplant recipients)

- Renal disease

- Anemia or hemoglobinopathy

- Neurologic or neurodevelopmental conditions (includes neuromuscular, neurovascular, neurodegenerative and neurodevelopmental conditions and seizure disorders [for children, includes febrile seizures and isolated developmental delay], but excludes migraines and psychiatric conditions without neurological conditions)

- $\quad$ Morbid obesity (body mass index [BMI] of 40 and over)

- Children six months to 18 years of age undergoing treatment for long periods with acetylsalicylic acid, because of the potential increase of Reye's syndrome associated with influenza

- People of any age who are residents of nursing homes and other chronic care facilities

- Adults 65 years of age and older

- All children 6-59 months of age

- Indigenous people

People capable of transmitting influenza to those at high risk:

- Health care and other care providers in facilities and community settings who, through their activities, are capable of transmitting influenza to those at high risk

- Household contacts, both adults and children, of individuals at high risk, whether or not the individual at high risk has been vaccinated, including: - Household contacts of individuals at high risk

- Household contacts of infants less than six months of age, as these infants are at high risk but cannot receive influenza vaccine

- Members of a household expecting a newborn during the influenza season

- Those providing regular child care to children 0-59 months of age, whether in or out of the home

- Those who provide services within closed or relatively closed settings to people at high risk (e.g. crew on a ship)

Others:

- People who provide essential community services

- People who are in direct contact with poultry infected with avian influenza during culling operations

Refer to Immunization of Persons with Chronic Diseases and Immunization of Immunocompromised Persons in Part 3 of the CIG for additional information about vaccination of people with chronic diseases (13)

Source: Table reproduced from NACl Seasonal Influenza Vaccine Statement for 2020-2021 (4) 
Recommended influenza vaccine options by age group and by dosage and route of administration by age are summarized in Tables 2 and 3, respectively.

\section{Table 2: Recommendations on the choice of influenza vaccine type for individual-level decision-making ${ }^{a}$ by age group}

\begin{tabular}{|c|c|c|}
\hline $\begin{array}{l}\text { Recipient by } \\
\text { age group }\end{array}$ & $\begin{array}{c}\text { Vaccine types } \\
\text { authorized for } \\
\text { use }\end{array}$ & $\begin{array}{c}\text { Recommendations on choice } \\
\text { of influenza vaccine }\end{array}$ \\
\hline 6-23 months & $\begin{array}{l}\text { - IIV3-SD } \\
\text { - IIV3-Adj } \\
\text { - IIV4-SD }\end{array}$ & $\begin{array}{l}\text { - Quadrivalent influenza vaccine } \\
\text { should be used in infants } \\
\text { without contraindications, } \\
\text { given the burden of influenza } \\
\text { B disease in this age group } \\
\text { and the potential for lineage } \\
\text { mismatch between the } \\
\text { predominant circulating strain } \\
\text { of influenza B and the strain in } \\
\text { a trivalent vaccine } \\
\text { - If a quadrivalent vaccine is not } \\
\text { available, any of the available } \\
\text { trivalent vaccines should be } \\
\text { used }\end{array}$ \\
\hline $2-17$ years $^{b}$ & $\begin{array}{ll}- & \text { IIV3-SD } \\
\text { - IIV4-SD } \\
\text { - } \text { LAIV4 }\end{array}$ & $\begin{array}{l}\text { - Either IIV4-SD or LAIV4 should } \\
\text { be used in children without } \\
\text { contraindications, including } \\
\text { those with non-immune } \\
\text { compromising chronic health } \\
\text { conditions, given the burden } \\
\text { of influenza B disease in this } \\
\text { age group and the potential } \\
\text { for lineage mismatch between } \\
\text { the predominant circulating } \\
\text { strain of influenza B and the } \\
\text { strain in a trivalent vaccine } \\
\text { - If IIV4-SD or LAIV4 is not } \\
\text { available, IIV3-SD should be } \\
\text { used } \\
\text { - IIV4-SD should be used for } \\
\text { children for whom LAIV is } \\
\text { contraindicated, such as in } \\
\text { children with: } \\
\text { Severe asthma } \\
\text { ○ Medically attended } \\
\text { wheezing in the seven } \\
\text { days prior to vaccination } \\
\text { Current receipt of aspirin } \\
\text { or aspirin-containing } \\
\text { therapy } \\
\text { Immune compromising } \\
\text { conditions, with the } \\
\text { exception of stable HIV } \\
\text { infection, if the child is } \\
\text { currently being treated } \\
\text { with HAART and has } \\
\text { adequate immune } \\
\text { function }\end{array}$ \\
\hline
\end{tabular}

Table 2: Recommendations on the choice of influenza vaccine type for individual-level decision-making ${ }^{a}$ by age group (continued)

\begin{tabular}{|c|c|c|}
\hline $\begin{array}{l}\text { Recipient by } \\
\text { age group }\end{array}$ & $\begin{array}{c}\text { Vaccine types } \\
\text { authorized for } \\
\text { use }\end{array}$ & $\begin{array}{c}\text { Recommendations on choice } \\
\text { of influenza vaccine }\end{array}$ \\
\hline $\begin{array}{l}2-17 \text { years }^{b} \\
\text { (continued) }^{\text {contined }}\end{array}$ & $\begin{array}{l}\text { - } \quad \text { IIV3-SD } \\
\text { - } \quad \text { IIV4-SD } \\
\text { - } \quad \text { LAIV4 } \\
\text { (continued) }\end{array}$ & $\begin{array}{l}\text { - LAIV4 may be given to } \\
\text { children with: } \\
\text { Stable, non-severe } \\
\text { asthma } \\
\text { Cystic fibrosis who are } \\
\text { not being treated with } \\
\text { immunosuppressive } \\
\text { drugs (e.g. prolonged } \\
\text { systemic corticosteroids) } \\
\text { Stable HIV infection, } \\
\text { if the child is currently } \\
\text { being treated with } \\
\text { HAART and has } \\
\text { adequate immune } \\
\text { function }\end{array}$ \\
\hline $18-59$ years & $\begin{array}{ll}\text { - } & \text { IIV3-SD } \\
\text { - } & \text { IIV4-SD } \\
\text { - } & \text { LAIV4 }\end{array}$ & $\begin{array}{l}\text { - Any of the available } \\
\text { influenza vaccines should } \\
\text { be used in adults without } \\
\text { contraindications } \\
\text { - IIV should be used for } \\
\text { adults for whom LAIV is } \\
\text { contraindicated or not } \\
\text { recommended, such as in: } \\
\text { o Pregnant women } \\
\text { - Adults with any of the } \\
\text { chronic health conditions } \\
\text { identified in Table 2, } \\
\text { including immune } \\
\text { compromising conditions } \\
\text { HCWs }\end{array}$ \\
\hline 60-64 years & $\begin{array}{l}\text { - } I I V 3-S D \\
\text { - IIV4-SD }\end{array}$ & $\begin{array}{l}\text { - Any of the available } \\
\text { influenza vaccines should } \\
\text { be used in those without } \\
\text { contraindications }\end{array}$ \\
\hline $\begin{array}{l}65 \text { years and } \\
\text { older }^{c}\end{array}$ & $\begin{array}{ll}\text { - } & \text { IIV3-SD } \\
\text { - } & \text { IIV3-Adj } \\
\text { - } & \text { IIV3-HD } \\
\text { - } & \text { IIV4-SD }\end{array}$ & $\begin{array}{l}\text { - IIV3-HD should be used over } \\
\text { IIV3-SD, given the burden of } \\
\text { influenza A(H3N2) disease } \\
\text { and the good evidence of } \\
\text { better protection compared } \\
\text { to IIV3-SD in adults } 65 \text { years of } \\
\text { age and older } \\
\text { ○ } \mathrm{NACl} \text { does not } \\
\text { make comparative } \\
\text { individual-level } \\
\text { recommendations on } \\
\text { the use of IIV3-Adj or } \\
\text { IIV4-SD over IIV3-SD, or } \\
\text { among IIV3-Adj, IIV3-HD, } \\
\text { and IIV4-SD } \\
\text { In the absence of any } \\
\text { specific product, any of } \\
\text { the available influenza } \\
\text { vaccines should be used }\end{array}$ \\
\hline \multicolumn{3}{|c|}{$\begin{array}{l}\text { Abbreviations: HAART, highly active antiretroviral therapy; HCW, health care worker; } \\
\text { IIV, inactivated influenza vaccine; IIV3-Adj, adjuvanted trivalent inactivated influenza vaccine; } \\
\text { IIV3-HD, high-dose trivalent inactivated influenza vaccine; IIV3-SD, standard-dose trivalent } \\
\text { inactivated influenza vaccine; IIV4-SD, standard-dose quadrivalent inactivated influenza vaccine; } \\
\text { LAIV, live attenuated influenza vaccine; LAIV4, quadrivalent live attenuated influenza vaccine; } \\
\text { NACI, National Advisory Committee on Immunization } \\
\text { a Recommendations for individual-level decision making are intended for individuals wishing to } \\
\text { protect themselves from influenza, or vaccine providers wishing to advise individual patients } \\
\text { about preventing influenza } \\
\text { b Refer to Table } 4 \text { of the NACI Seasonal Influenza Vaccine Statement for 2020-2021 for a summary } \\
\text { of vaccine characteristics of LAIV compared with IIV in children } 2-17 \text { years of age (4) } \\
\text { c Refer to Table } 5 \text { NACI Seasonal Influenza Vaccine Statement for } 2020-2021 \text { for a comparison of } \\
\text { the vaccine characteristics of influenza vaccine types available for use in adults } 65 \text { years of age } \\
\text { and older (4) } \\
\text { Source: Table adapted from NACI Seasonal Influenza Vaccine Statement for 2020-2021 (4) }\end{array}$} \\
\hline
\end{tabular}


Table 3: Recommended dose and route of administration, by age, for influenza vaccine types authorized for the 2020-2021 influenza season

\begin{tabular}{|c|c|c|c|c|c|}
\hline \multirow[b]{2}{*}{ Age group } & \multicolumn{4}{|c|}{$\begin{array}{l}\text { Influenza vaccine type } \\
\text { (route of administration) }\end{array}$} & \multirow[b]{2}{*}{$\begin{array}{l}\text { Number of doses } \\
\text { required }\end{array}$} \\
\hline & $\begin{array}{c}\text { IIV3-SD }{ }^{\mathrm{a}} \text { or } \\
\text { IIV4-SD }^{\mathrm{b}} \\
\text { (Intramuscular) }\end{array}$ & $\begin{array}{c}\text { IIV3-Adj }^{\mathrm{c}} \\
\text { (Intramuscular) }\end{array}$ & $\begin{array}{c}\text { IIV3-HD } \\
\text { (Intramuscular) }\end{array}$ & $\begin{array}{c}\text { LAIV4e } \\
\text { (Intranasal) }\end{array}$ & \\
\hline 6-23 months & $0.5 \mathrm{~mL}^{f}$ & $0.25 \mathrm{~mL}$ & - & 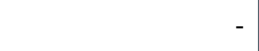 & $1-2^{g}$ \\
\hline $2-8$ years & $0.5 \mathrm{~mL}$ & - & - & $\begin{array}{r}0.2 \mathrm{~mL} \\
(0.1 \mathrm{~mL} \text { per nostril) }\end{array}$ & $1-2^{g}$ \\
\hline 9-17 years & $0.5 \mathrm{~mL}$ & - & - & $\begin{array}{r}0.2 \mathrm{~mL} \\
(0.1 \mathrm{~mL} \text { per nostril) }\end{array}$ & 1 \\
\hline $18-59$ years & $0.5 \mathrm{~mL}$ & - & - & $\begin{array}{r}0.2 \mathrm{~mL} \\
(0.1 \mathrm{~mL} \text { per nostril) }\end{array}$ & 1 \\
\hline $60-64$ years & $0.5 \mathrm{~mL}$ & - & - & - & 1 \\
\hline 65 years and older & $0.5 \mathrm{~mL}$ & $0.5 \mathrm{~mL}$ & $0.5 \mathrm{~mL}$ & - & 1 \\
\hline
\end{tabular}

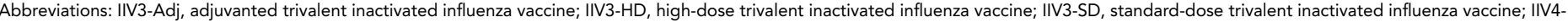
SD, standard-dose quadrivalent inactivated influenza vaccine; LAIV4, quadrivalent live attenuated influenza vaccine; -, no data

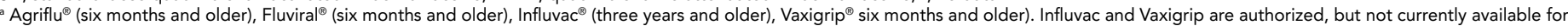
sale in Canada

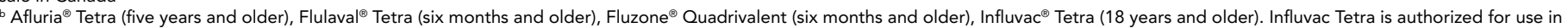

Canada in adults 18 years and older; however, $\mathrm{NACl}$ has not specifically reviewed this product

' Fluad Pediatric ${ }^{\circledast}$ (6-23 months) or Fluad ${ }^{\circledast}$ (65 years and older)

${ }^{\circ}$ Fluzone ${ }^{\circledR}$ High-Dose $(65$ years and older)

- FluMist ${ }^{\oplus}$ Quadrivalent (2-59 years)

${ }^{\mathrm{f}}$ Evidence suggests moderate improvement in antibody response in infants, without an increase in reactogenicity, with the use of full vaccine doses ( $\left.0.5 \mathrm{~mL}\right)$ for unadjuvanted inactivated influenza

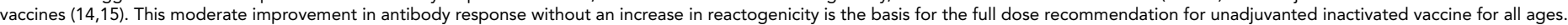
For more information, refer to Statement on Seasonal Influenza Vaccine for 2011-2012 (16)

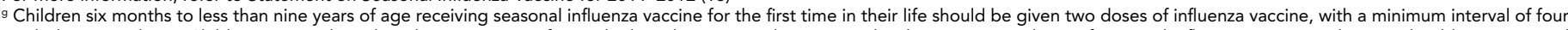

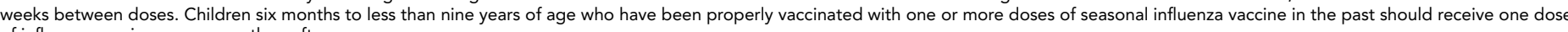
of influenza vaccine per season thereafter

Source: Table reproduced from NACI Seasonal Influenza Vaccine Statement for 2020-2021 (4)

\section{Conclusion}

$\mathrm{NACl}$ continues to recommend annual influenza vaccination for all individuals aged six months and older (noting product-specific age indications and contraindications), with particular focus on people at high risk of influenza-related complications or hospitalization. In addition, people capable of transmitting to high risk individuals, people who provide essential community services and people in direct contact during culling operations with poultry infected with avian influenza are particularly recommended to receive the influenza vaccine. For the 2020-2021 influenza season, NACl continues to recommend that, in the absence of contraindications, HCWs and other care providers in facilities and community settings should be vaccinated annually against influenza, and continues to recommend the inclusion of this group among those particularly recommended to receive the influenza vaccine. $\mathrm{NACl}$ also newly recommends that LAIV may be considered as an option for children 2-17 years of age with stable HIV infection HAART and with adequate immune function.

\section{Authors' statement}

KY — Writing, original draft, review, editing

IG - Review, editing

$\mathrm{RH}$ - Review, editing

The National Advisory Committee on Immunization (NACl)

Canadian Immunization Guide Chapter on Influenza and Statement on Seasonal Influenza Vaccine for 2020-2021 was prepared by K Young, A Sinilaite, L Zhao, and I Gemmill on behalf of the NACI Influenza Working Group and was approved by $\mathrm{NACl}$.

\section{Conflict of interest}

None.

\section{Acknowledgements}

Influenza Working Group members: I Gemmill (Chair), R Harrison (Vice-Chair), C Bancej, L Cochrane, N Dayneka, L Grohskopf, D Kumar, J Langley, P Wolfe-Roberge, J McElhaney, A McGeer, D Moore, S Smith, B Warshawsky and J Xiong 
NACI members: $C$ Quach (Chair), S Deeks (Vice-Chair), N Dayneka, P De Wals, V Dubey, R Harrison, K Hildebrand, C Rotstein, M Salvadori, B Sander, N Sicard and S Smith

Liaison representatives: LM Bucci (Canadian Public Health Association), E Castillo (Society of Obstetricians and Gynaecologists of Canada), A Cohn (Centers for Disease Control and Prevention, United States), J Emili (College of Family Physicians of Canada), M Naus (Canadian Immunization Committee), D Moore (Canadian Paediatric Society) and A Pham-Huy (Association of Medical Microbiology and Infectious Disease Canada)

Ex-officio representatives: J Gallivan (Marketed Health Products Directorate, Health Canada [HC]), E Henry (Centre for Immunization and Respiratory Infectious Diseases [CIRID], Public Health Agency of Canada [PHAC]), M Lacroix (Public Health Ethics Consultative Group, PHAC), J Pennock (CIRID, PHAC), R Pless (Biologics and Genetic Therapies Directorate, $\mathrm{HC}), \mathrm{G}$ Poliquin (National Microbiology Laboratory, PHAC) and T Wong (First Nations and Inuit Health Branch, Indigenous Services Canada)

The National Advisory Committee on Immunization acknowledges and appreciates the contribution of $\mathrm{O}$ Baclic, A House, S Ismail, M Laplante and M Tunis to this statement.

\section{Funding}

The work of the National Advisory Committee on Immunization is supported by the Public Health Agency of Canada.

\section{References}

1. Statistics Canada. The 10 leading causes of death, 2011. Ottawa (ON): Statistics Canada; 2018. http://www.statcan.gc.ca/pub/82625-x/2014001/article/11896-eng.htm

2. Schanzer DL, McGeer A, Morris K. Statistical estimates of respiratory admissions at-tributable to seasonal and pandemic influenza for Canada. Influenza Other Respir Viruses 2013 Sep;7(5):799-808. DOI PubMed

3. Schanzer DL, Sevenhuysen C, Winchester B, Mersereau T. Estimating influenza deaths in Canada, 1992-2009. PLoS One 2013 Nov;8(11):e80481. DOI PubMed

4. National Advisory Committee on Immunization. Canadian Immunization Guide Chapter on Influenza and Statement on Seasonal Influenza Vaccine for 2020-2021. Ottawa (ON): PHAC; 2020. https://www.canada.ca/en/public-health/services/ publications/vaccines-immunization/canadian-immunizationguide-statement-seasonal-influenza-vaccine-2020-2021.html

5. National Advisory Committee on Immunization. Evidence-based recommendations for immunization-Methods of the National Advisory Committee on Immunization. Can Commun Dis Rep. 2009 Jan;35(ACS-1):1-10. https://www.canada.ca/en/publichealth/services/reports-publications/canada-communicabledisease-report-ccdr/monthly-issue/2009-35/methods-nationaladvisory-committee-immunization.html
6. Carman WF, Elder AG, Wallace LA, McAulay K, Walker A, Murray $G D$, Stott DJ. Effects of influenza vaccination of health-care workers on mortality of elderly people in long-term care: a randomised controlled trial. Lancet 2000 Jan;355(9198):93-7. DOI PubMed

7. Hayward AC, Harling R, Wetten S, Johnson AM, Munro S, Smedley J, Murad S, Watson JM. Effectiveness of an influenza vaccine programme for care home staff to prevent death, morbidity, and health service use among residents: cluster randomised controlled trial. BMJ 2006 Dec;333(7581):1241. DOI PubMed

8. Potter J, Stott DJ, Roberts MA, Elder AG, O'Donnell B, Knight $P V$, Carman WF. Influ-enza vaccination of health care workers in long-term-care hospitals reduces the mortality of elderly patients. J Infect Dis 1997 Jan;175(1):1-6. DOI PubMed

9. Lemaitre $\mathrm{M}$, Meret $\mathrm{T}$, Rothan-Tondeur $\mathrm{M}$, Belmin $\mathrm{J}$, Lejonc $\mathrm{JL}$, Luquel L, Piette F, Sa-lom M, Verny M, Vetel JM, Veyssier P, Carrat F. Effect of influenza vaccination of nursing home staff on mortality of residents: a cluster-randomized trial. J Am Geriatr Soc 2009 Sep;57(9):1580-6. DOI PubMed

10. Harris RP, Helfand M, Woolf SH, Lohr KN, Mulrow CD, Teutsch SM, Atkins D; Methods Work Group, Third US Preventive Services Task Force. Current methods of the US Preventive Services Task Force: a review of the process. Am J Prev Med 2001 Apr;20(3 Suppl):21-35. DOl PubMed

11. Kuster SP, Shah PS, Coleman BL, Lam PP, Tong A, Wormsbecker $A, M c G e e r A$. Incidence of influenza in healthy adults and healthcare workers: a systematic review and meta-analysis. PLoS One 2011;6(10):e26239. DOl PubMed

12. National Advisory Committee on Immunization. $\mathrm{NACl}$ Recommendation on the use of live-attenuated influenza vaccine (LAIV) in HIV-infected individuals. Ottawa (ON): Public Health Agency of Canada; 2018.

13. Public Health Agency of Canada. Canadian Immunization Guide: Part 3 - Vaccination of specific populations. Ottawa (ON): PHAC; 2015. https://www.canada.ca/en/public-health/services/ publications/healthy-living/canadian-immunization-guide-part-3vaccination-specific-populations/page-7-immunization-personswith-chronic-diseases.html

14. Langley JM, Vanderkooi OG, Garfield HA, Hebert J, Chandrasekaran V, Jain VK, Fries L. Immunogenicity and safety of 2 dose levels of a thimerorsal-free trivalent seasonal influenza vaccine in children aged 6-35 months: A randomized, controlled trial. J Pediatric In-fect Dis Soc 2012 Mar;1(1):55-63.

DOI PubMed

15. Skowronski DM, Hottes TS, Chong M, De Serres G, Scheifele DW, Ward BJ, Halperin SA, Janjua NZ, Chan T, Sabaiduc S, Petric M. Randomized controlled trial of dose response to influenza vaccine in children aged 6 to 23 months. Pediatrics 2011 Aug;128(2):e276-89. DOI PubMed

16. National Advisory Committee on Immunization. Statement on Seasonal Influenza Vaccine for 2011-2012. Can Commun Dis Rep. 2011;37(ACS-5):1-55. DOI 